\title{
PARENTS' EFFORTS TO IMPROVE THE UNDERSTANDING IN CARING FOR CHILDREN WITH MENTAL RETARDATION
}

\author{
Aulia Nailul Muna ${ }^{1}$, Sunardi ${ }^{2}$ dan Herry Widyastono ${ }^{3}$ \\ ${ }^{1,2,3}$ University of Sebelas Maret Surakarta \\ Jl. Ir. Sutami No.36, Kentingan, Kec. Jebres,Surakarta City, Central Java 57126 \\ auliya_martini@yahoo.com sunardi.ipuns@gmail.com \\ herrywidyastono@yahoo.com
}

\begin{abstract}
The purpose of this study is to find parents' efforts to improve understanding in caring for children with mental retardation in Kendal district. The subjects of this study were parents who have mentally retarded children. This study uses a qualitative case study method. The data collection uses interview and observation technique and the technical data analysis uses descriptive analysis. The results of this study found that parents are lack of understanding in taking care children with mental retardation and parents need to improve their understanding of taking care children with mental retardation.
\end{abstract}

Keywords: Improving Understanding, Caring for Children, and Children with Mental Retardation

\begin{abstract}
Abstrak: Tujuan penelitian ini adalah untuk mengetahui upaya orang tua untuk meningkatkan pemahaman kepedulian terhadap anak keterbelakangan mental di kabupaten Kendal. Subjek penelitian ini adalah para orang tua yang memiliki anak keterbelakangan mental. Penelitian ini menggunakan metode studi kasus kualitatif. Pengumpulan data menggunakan wawancara dan teknik pengamatan dan teknik analisis data menggunakan analisis deskriptif. Hasil penelitian ini menemukan bahwa para orang tua kurang pemahaman dalam merawat anak keterbelakangan mental dan para orang tua perlu untuk meningkatkan pemahaman mereka tentang merawat anak keterbelakangan mental.
\end{abstract}

Kata Kunci: Peningkatan Pemahaman, Perawatan Anak, Anak Keterbelakangan Mental

Sumber: ICEHoS - International Conference on Education, Humanities, and Social Science

$\mathrm{E}$ very child is special and they are mandate from God that must be guarded, cared for and guided as good as possible. Children are a valuable gift for every family. Every parent certainly expects the presence of children who are physically and mentally healthy. But, not every child grows and develops as their parents' expectation. Children with special needs were children who have a different characteristic with children in general because they have problems in growth and development (Atmaja, 2017). 
One of children with special needs type are mental retardation. According to Soemantri (2005), mental retardation is a term used to refer to children who have intellectual ability below average. Then, according to the guidelines for the classification and diagnosis of mental disorders III (2013) mental retardation is a state of mental development that is stopped or incomplete which is marked by the occurrence of skill obstacles during the development period.

Furthermore, the American Association for Mental Deficiency (2010) defines mental retardation as an abnormality where intellectual function is lower than general average with the IQ value of 84 or below. Usually, mentally retarded children will have difficulty in Adaptive Behavior. The Ministry of Women's Empowerment and Child Protection of the Republic of Indonesia (2013) stated that mentally retarded children are children who experience limitations or speciality in physical, mental-intellectual, social, and emotional. It significantly influences the process of growth or development compared to their peer. In this case, mentally retarded children cannot achieve independence in accordance with the standards of independence and social responsibility of normal children. In addition, they will also experience problems in academic skills and communication with peer age groups. If there is no guidance and direction from parents, they will get love and affection (Murtiningsih, 2013).

It is explained in Law Number 20 of 2003 concerning National Education in article 5 paragraph 1 that every citizen has the same right to obtain quality education. Article 5 paragraph 2 states that Citizens who have physical, emotional, mental, intellectual and / or social disabilities are entitled to special education. In addition, Law No. 1 of 1974 concering marriage article 45 paragraph 2 states that parents are obliged to maintain and educate children as well as possible until the child is able to stand on its own.

Therefore, parents' love towards their children should be true affection (Purwanto, 2009). In an effort to produce a strong and quality future generation, it is necessary to have consistent and continuous efforts 
from parents in carrying out the tasks of parents that are raising, caring for and educating their children until they are mature and able to be independent where this task is a parental obligations (Gunawan, 2013). According to Surbakti (2012), every child whoever they are, wherever they are, and however they are certainly want or crave the presence, existence, care, and assistance of parents in their lives.

One of the parents' tasks is fulfilling the needs of their children such as training their children to take care of themselves, teaching them how to eat, urinate, talk, walk, and pray. It will imprint on the child because it is closely related to his personal development. The attitude of parents greatly influences the child's development. Their attitude such as acceptance, refusal, affection, indifference, patience, haste, protecting, neglecting directly influence children's emotional reactions (Hasbullah, 2011).

For mentally retarded children, parents' guidance is absolutely necessary and it needs a good understanding about mental retardation so that children get their needs. Giving inappropriate guidance would pose dependence in children with mental retardation. In addition, the lack of giving special attention and treatment to mentally retarded children for example spoiling the children will give them a bad influence. They will not become independent individuals. Improper guidance can give a negative impact on their social. Mentally retarded children who cannot be independent will be accustomed to anything served by their parents. Thus, it makes them unproductive in doing their activities.

Parents should understand the behavioral barriers in mentally retarded children at least on basic skills or what have to be guided as early as possible such as personal living skills, skills in interpersonal relationships, and social living skills.

In an effort to resolve behavioral barriers for children with mental retardation, it is necessary to develop their ability in conducting activities related to their life and provide treatment with special 
attention so that they do not burden others.

However during this time, there were parents who did not understand the caring of mentally retarded children. This was indicated by interviews with 10 parents in Kendal district who stated that parents of children with mental retardation were expecting their children to recover and could be like other normal children. In addition, there were many parents of mentally retarded children who did not know the need of developing the mentally retarded children development. They should know about their children development such as communicating, caring for themselves, socializing, skills in maintaining health, and safety. In addition, they should know about practicing their children to work in the future. Parents felt pessimistic and consider themselves unable to care for mentally retarded children. They expected their children to be physically fit. In addition, they did not have much hope for their children to develop their abilities and behave independently to achieve special achievements. Parents felt that it is difficult to care for mentally retarded children. From the explanation above, the researcher wants to find out "How parents' efforts in improving understanding in caring for mentally retarded children in Kendal district?"

\section{METHODOLOGY}

The type of research entitled parents' efforts in improving understanding in caring for mentally retarded children in Kendal district is qualitative approach where the research procedure produces descriptive data in the form of speech or writing and the behavior of those who observed. Researcher used this method because this study aims to determine the extent of parental efforts in caring for mentally retarded children. The researcher wanted to know activities given by parents to mentally retarded children at home. In addition, the reasearcher wanted to know in what ways the parents implement activities towards 
mentally retarded children and its impact towards children with mental retardation. The procedure in this study through several stages that is: observation, researchers observed parents of mentally retarded children who attend SLB Swadaya Kendal. The next stage is the selection of subjects in research. The subjects in this study were parents and families of mentally retarded children. In the next stage, the research conducted interviews with the subject. The last stage is data analysis. In this stage, the researcher analyzed obtained data and summarized research results descriptively.

\section{Result}

The results of research on parents' efforts to improve understanding in caring for children with mental retardation in Kendal District, based on interviews with respondent 1 who are mother of mentally retarded children, stated that conducted activities with her children are only serve without giving opportunity for children to train and guide to be independence. The reason for the mentally retarded child mother is that she feels very difficult and it will take longer time. In addition, the mother told that she realized the impact of the treatment will make the child not independent and always depend on others.

Respondent 2, who is a mother of a mentally retarded child, stated that the activities given to the child so far were teaching mentally retarded child in the academic field, in teaching given such as counting, reading, and writing. But, the mother complained of her child who is very difficult to understand what has been taught, get bored, and angry easily. The mother of a mentally retarded child really hoped that the mentally retarded child can recover and be able to attend public schools. The mother had made an effort by getting an alternative mediciation in order tocure her child. Respondent 3, who is a mother of a mentally retarded child, stated that the conducted activity with her child were leaving mentally retarded child without treatment and attention because parents find it 
difficult to communicate with the child. In addition, mentally retarded children tend to be more silent and less responding to what the mother conveys to the child. The mother was also aware of the impact of the lack of attention and treatment for mentally retarded children.

Respondent 4, who is a mother of a mentally retarded child, stated that conducted activities with her child were serving the child well such as eating, bathing and other activities. All the activities are always fulfilled but the mother are ashamed and looked like hindering the child in developing their ability to achieve independence. In addition, the mother realized that she lack of patience in educating and guiding mentally retarded children. Respondent 5, who is a mother of a mentally retarded child, stated that the conducted activities were guiding and teaching self-care skills such as bathing, toilet training, and eating properly. But, the mother of a mentally retarded child complains about mentally retarded child who is not like other normal child in their age. The mentally retarded child prefers to play with children under his age.

Respondents 6, who is a father of mentally retarded twin, stated that the conducted activity were giving love towards children and serving them wholeheartedly. Sometimes he cried seeing the condition of his children. The father had visited alternative medicine as an effort to minimize the condition of the children. He hoped that the children are able to respond to what was conveyed by his father, the person who tried to communicate with them, and responding to whatever his father was aiming for. Respondent 7, who is a mother of mentally retarded child, stated that the conducted activities with the child were teaching writing, counting, and reading. But, the mother did not do it intensely or occasionally because the mentally retarded child is easily angry and bored so it made her angry. In addition, the mother wanted her child to be able to interact with child's peers. 
Respondent 8 , who is a mother of a mentally retarded child, stated that the conducting activities were serving the child well and giving love wholeheartedly. She did it because the mother was not sure about the ability of the child when the child was taught, mentored, and directed to achieve independence as expected. Respondent 9, who is the father of a mentally retarded child, stated that the conducted activities were giving love and more attention so that the mentally retarded child tended to be spoiled. It was occured because the father felt so pity seeing the mentally retarded child. Respondent 10, who is a mother of a mentally retarded child, stated that the conducted activities were allowing any activities conducted by the child and tending to not responding to child because the mother has a busy schedule besides caring for the child. In addition, the child was cared for by her neighbor every day.

\section{DISCUSSION}

Based on the result of these studies, it seems that parents do not have understanding in caring of children with mental retardation. Some of them state that they want their children to be cured and become normal children. This statement proves that parents do not have understanding about children with mental retardation where mental retardation is defined by Kirk in Efendi (2006) as a condition that has nothing to do with the disease or the same as a disease. Mental retardation is not a disease but a condition so it cannot be cured or treated with any drug.

Furthermore, there is a need of method in teaching children with mental retardation. The method should cover about reading, counting, and writing like what normal children learn. Based on the characteristics of mentally retarded children who forget easily, it needs concrete and applicative teaching for them. Parents find it difficult to teach a thing, difficult to understand, and easy to forget. In this case, parents need to understand and know that mentally 
retarded children have slow comprehension. It is required to use learning media in the form of concrete objects to get their attention because mentally retarded children get bored quickly and easily distracted (Meimulyani and Caryoto, 2013).

In terms of communication, it is still difficult and cannot adjust to peers. The resolution for the cases is giving formal training organized by the local government or from educational institutions. Also, it can be in a form of non-formal training conducted by a community of parents who have children with mental retardation. By joining the training, the parents get the knowledge and understanding of how to care for their children so that they can care of their children based on the children's condition and need. Based on the explanation above, the improvement of understanding about mentally retarded children for parents is needed. The resolution for the case is giving formal training organized by the local government or from educational institutions. In addition, it can be in a form of non-formal training conducted by a community of parents who have children with mental retardation. By joining the training, the parents will get the knowledge and understanding of how to care for children with mental retardation. Therefore, the children are able to be independence and do not always depend on others.

\section{CONCLUSION}

The role of parents in caring for mentally retarded children is very influential for the growth and development of children. Not only that, it takes understanding so that children can maximize their potential. In addition, attention and special treatment is needed for children with mental retardation. The results of this study found that parents got difficulties in caring for mentally retarded children. Many of them expected mentally retarded children to recover and be able to join public schools. Also, they are difficult to communicate and feel confused 
because their children prefer to play with children under the children's age. In order to fulfill the needs of mentally retarded children, parents have to improve their understanding in caring for children with mental retardation.

\section{REFERENCE}

American Association on Intellectual and Developmental Disabilities. (2010). FAQ on Intellectual Disability. (Diunduh dari htpp://www.acar.org/content_104 $. c f m)$

American Psychiatric Association.

(2013). Diagnostic and statistical manual of mental disorders (5th ed).

Washington, DC: Author.

Amin, Mohammad. (1995).

Ortopedagogik Anak

Tunagrahita. Jakarta:

Departemen Pendidikan dan

Kebudayaan

Atmaja, J. R. (2017). Pendidikan dan Bimbingan Anak Berkebutuhan Khusus. Bandung: PT Remaja Rosdakarya.

Efendi, M. (2006). Pengantar
Psikopedagogik Anak Berkelainan. Jakarta: PT Bumi Aksara. Lestari, S. (2012). Psikologi Keluarga. Jakarta: Prenada Media Group.

Mahmud Gunawan, d. (2013). Pendidikan Agama Islam dalam Keluarga. Jakarta: Akademia Permata

Maria, C., Pereira, G., Maria De, S., \& Faria, M.(2013). Emotional Development in Children with Intellectual Disability $-A$ Comparative Approach with "Normal" Children. Journal of Modern Education Review, 3(2), 2155-7993.

Meimulyani,Y dan Caryoto (2013)

Media Pembelajaran Adaptif bagi Anak Berkebutuhan Khusus.

Bandung: PT Luxima Metro Media

Mumpuniarti. (2003). Ortodidaktik Tunagrahita. Yogyakarta: FIP UNY.

Mumpuniarti. (2007). Pembelajaran Akademik Bagi Tunagrahita. Yogyakarta: FIP UNY.

Muritiningsi, R. P. (2013). Kiat Sukses Mengasuh Anak Berkebutuhan Khusus. Yogyakarta: Ar-Ruzz Media. 
Peraturan Menteri Pemberdayaan

Perempuan dan Perlindungan

Anak Republik Indonesia

(2013) Tentang Kebijakan

Penanganan

Anak

Berkebutuhan Khusus

Purwanto, M. N. (2009). Ilmu

Pendidikan Praktis dan Teoritis.

Bandung: $\quad$ PT $\quad$ Remaja

Rosdakarya.

Rachmayana, D. (2013). Diantara

Pendidikan Luar Biasa Menuju

Anak Masa Depan yang Inklusif.

Jakarta: PT Luxima Metro Media.

Rachmawati, Sarah Nur dan Masykur, Achmad Mujab.(2016) Pengalam

Ibu Yang Memiliki Anak Down

Syndrome. Jurnal Empati, Vol. 5, 822-830

Surbakti, E. (2012). Parenting Anak-

Anak. jakarta: PT Elex Media

Komputindo.

Vani, Gabriela Chrisnita, Raharjo,

Santoso Tri dan Hidayat, Eva

Nuriyah.(2015) Pengasuhan (Good

Parenting) Bagi Anak Dengan

Disabilitas Prosiding KS: RISET \&

PKM. ISSN: 2442-4480.Vol. 2.

Hlm: 1 - 146

Wijaya, Yeny Duriana (2015) Positif

Parenting Program (Triple P)

Sebagai Usaha Untuk Menurunkan
Pengasuhan Disfungsional Pada

Orang Tua Yang Mempunyai Anak Berkebutuhan Khusus (Dengan Diagnosa Autis dan ADHD). Jurnal Psikologi Vol. 13 No. 1 